medRxiv preprint doi: https://doi.org/10.1101/2020.05.18.20097220; this version posted May 20, 2020. The copyright holder for this preprint (which was not certified by peer review) is the author/funder, who has granted medRxiv a license to display the preprint in perpetuity.

It is made available under a CC-BY-NC-ND 4.0 International license .

\title{
Hyperpyrexia leading to death in a patient with severe COVID-19 disease
}

Tanu Singhal MD*, Sourabh Phadtare MD**, Sunil Pai DNB**, Amit Raodeo DM**

*Department of Infectious Disease

***Department of Critical Care Medicine

Kokilaben Dhirubhai Ambani Hospital and Medical Research Institute, Mumbai, India

\section{Corresponding author}

Tanu Singhal

Consultant Infectious Disease

Kokilaben Dhirubhai Ambani Hospital and Medical Research Institute, Mumbai, India

Email: tanusinghal@yahoo.com

\begin{abstract}
We describe here the clinical course of a 42 year old male with severe COVID 19 disease treated at a private hospital in Mumbai, India. This patient with very high inflammatory markers at admission was treated with supportive care, mechanical ventilation, anticoagulation, hydroxychloroquine, corticosteroids, tocilizumab, intravenous insulin, antibiotics, sedation and paralysis. There was sustained improvement in his respiratory status and decline in ventilator settings with decline and normalization of CRP, D dimer and PCT. However high fever persisted that did not respond to paracetamol and NSAIDS. On day 8 of admission his axillary temperature touched $107 \mathrm{~F}$ followed by rapid clinical deterioration and death within the next 12 hours, Blood cultures were consistently sterile. While death was related to hyperpyrexia, the cause of this hyperpyrexia is uncertain.
\end{abstract}


medRxiv preprint doi: https://doi.org/10.1101/2020.05.18.20097220; this version posted May 20, 2020. The copyright holder for this preprint (which was not certified by peer review) is the author/funder, who has granted medRxiv a license to display the preprint in perpetuity.

It is made available under a CC-BY-NC-ND 4.0 International license.

\section{Case report}

As the COVID-19 pandemic is evolving, new and atypical manifestations of the disease are being described regularly (1,2,3). We report a case of a 42 year old male with COVID-19 who was admitted to the COVID ICU of a tertiary care private hospital in Mumbai, India who had persistent fever and then hyperpyrexia leading to death. The Institutional Ethics and Research Committee gave a waiver for ethical approval for publication of this data.

This was a 42 year old male with normal body mass index (BMI) and who also had diabetes for past 8 years controlled on oral medications. He had symptoms of fever, cough and myalgia and after 6 days of symptoms tested positive for COVID-19 by RT PCR in the oropharyngeal swab. He was admitted to a local hospital on day 8 of illness and give symptomatic and supportive care. However he soon became breathless and was transferred to the study site on day 10 of illness. At admission he was drowsy, not obeying commands and tachypneic. His blood pressure was $146 / 62 \mathrm{~mm}$ of $\mathrm{Hg}$ and respiratory rate was $42 /$ minute and saturation on oxygen by mask was $63 \%$. He was intubated and mechanically ventilated at arrival. His initial investigations revealed a $\mathrm{Hb}$ of 13.1 , TLC of $10,720 / \mu 1$ with an absolute lymphocyte count of 400 and ANC:ALC ratio of 25 . The platelet count was $303000 / \mathrm{mm}^{3}$. The serum CRP was $20 \mathrm{mg} / \mathrm{dl}$ with a procalcitonin of $1.5 \mathrm{ng} / \mathrm{ml}$. The serum LDH $645 \mathrm{U} / \mathrm{Land}$ CPK was $308 \mathrm{U} / \mathrm{L}$. The D dimer levels were more than $10000 \mathrm{FEU}$ ng/ml. The serum creatinine was normal at $0.85 \mathrm{mg} / \mathrm{dl}$. The liver function tests and coagulation profile (PT/ PTT) were normal. Blood cultures were sent. CXR showed bilateral infiltrates. Treatment was initiated with piperacillin tazobactam, azithromycin, hydroxychloroquine and methylprednisolone $30 \mathrm{mg}$ twice daily. The patient was sedated with fentanyl and midazolam and paralysed with atracurium. On Day 0 of hospitalization the patient was also given tocilizumab $400 \mathrm{mg}$ two doses 24 hours apart. Therapeutic 
medRxiv preprint doi: https://doi.org/10.1101/2020.05.18.20097220; this version posted May 20, 2020. The copyright holder for this preprint (which was not certified by peer review) is the author/funder, who has granted medRxiv a license to display the preprint in perpetuity. It is made available under a CC-BY-NC-ND 4.0 International license .

anticoagulation with enoxaparin $60 \mathrm{mg}$ twice daily was also initiated. Intravenous insulin was given to control blood sugars. Over the next 2 days the patient needed high ventilator settings with PEEP of $12 \mathrm{~cm}$ of $\mathrm{H}_{2} \mathrm{O}, \mathrm{FiO}_{2}$ of $70 \%$ with which the arterial $\mathrm{PaO}_{2}$ remained around $60 \mathrm{~mm}$ of $\mathrm{Hg}$. After 48-72 hours there was decline in his ventilator requirements to a $\mathrm{FiO}_{2}$ of $40 \%$ and a PEEP of 6 with $\mathrm{PaO}_{2}$ of more than $100 \mathrm{~mm}$ of $\mathrm{Hg}$. During the next 5 days there was a steady decline in inflammatory markers including CRP, D-Dimer, LDH and procalcitonin (Table 1) and rise in absolute lymphocyte counts and platelet counts. However the patient continued to run high fever ranging from $101-102^{\circ} \mathrm{F}$. This fever did not respond to intravenous paracetamol. The blood and urine cultures were sterile and there was no other clinical focus of infection. Trial of ibuprofen, naproxen and even colchicine was given with no effect. External cooling measures were employed with which there was transient improvement. This fever was associated with tachycardia but there was no hypotension, oliguria or lactic acidosis. However on day 7, the fever touched $107^{\circ} \mathrm{F}$. This was associated with high IL-6 levels of 220, high CPK of $12746 \mathrm{U} / 1$ and high ferritin levels of $7171 \mathrm{ng} / \mathrm{ml}$ but negative CRP and PCT. At this time the systolic BP dropped to $70 \mathrm{~mm}$ of $\mathrm{Hg}$. Aggressive cooling with cold saline gastric lavage, fan, cooling blanket was initiated. Vasopressors were started, repeat blood cultures sent and empiric therapy with polymyxin B, meropenem and caspofungin was initiated. There was progressive downhill course with refractory hypotension, hyperthermia, oliguria, lactic acidosis and eventual cardiac arrest about 12 hours from the time the temperature touched $107^{\circ} \mathrm{F}$.

The non resolution of fever in the index case despite improving respiratory status, decline in inflammatory markers and no evidence of infection was puzzling. The most likely cause of this fever would be a cytokine storm especially since there was elevation of IL-6 and ferritin. But the other inflammatory markers including CRP and PCT were negative and D dimer had shown a 
medRxiv preprint doi: https://doi.org/10.1101/2020.05.18.20097220; this version posted May 20, 2020. The copyright holder for this preprint (which was not certified by peer review) is the author/funder, who has granted medRxiv a license to display the preprint in perpetuity.

It is made available under a CC-BY-NC-ND 4.0 International license .

sustained decline. Non response of this fever to NSAIDS and paracetamol suggested that fever could be due to temperature dysregulation (central fever). While there was no obvious neurologic deficit and the pupils were equal and reacting, it was not possible to assess the sensorium as patient was constantly sedated throughout is hospital stay. Neurologic involvement in COVID-19 has been described (4) The possibility of drug induced hyperthermia was also considered since the CPK was elevated on the day of hyperthermia. The urine myoglobin however was negative $825.9 \mu \mathrm{g} / \mathrm{ml}$ (cut off $1000 \mu \mathrm{g} / \mathrm{ml}$ ) and the treatment chart review was negative for drugs causing hyperthermia (5). A PUBMED literature search using keywords"malignant hyperthermia" or "hyperpyrexia" and "COVID 19 did not yield any results.

While we are still not certain about the cause of hyperpyrexia, the temporal profile of events suggests that it was hyperpyrexia and resulting cellular dysfunction that caused death of this patient with COVID 19. This phenomenon should also be added to the already long list of atypical manifestations of COVID-19.

\section{References}

1. Tay HS, Harwood R. Atypical presentation of COVID-19 in a frail older person [published online ahead of print, 2020 Apr 21]. Age Ageing. 2020;afaa068. doi:10.1093/ageing/afaa068

2. Kim J, Thomsen T, Sell N, Goldsmith AJ. Abdominal and testicular pain: An atypical presentation of COVID-19 [published online ahead of print, 2020 Mar 31]. Am J Emerg Med. 2020;S0735-6757(20)30194-7. doi:10.1016/j.ajem.2020.03.052 
medRxiv preprint doi: https://doi.org/10.1101/2020.05.18.20097220; this version posted May 20, 2020. The copyright holder for this preprint (which was not certified by peer review) is the author/funder, who has granted medRxiv a license to display the preprint in perpetuity. It is made available under a CC-BY-NC-ND 4.0 International license .

3. Ferrey AJ, Choi G, Hanna RM, et al. A Case of Novel Coronavirus Disease 19 in a Chronic Hemodialysis Patient Presenting with Gastroenteritis and Developing Severe Pulmonary Disease. Am J Nephrol. 2020;1-6. doi:10.1159/000507417.

4. Paniz-Mondolfi A, Bryce C, Grimes Z, et al. Central Nervous System Involvement by Severe Acute Respiratory Syndrome Coronavirus -2 (SARS-CoV-2). J Med Virol. 2020;10.1002/jmv.25915. doi:10.1002/jmv.25915

5. Walter E, Carraretto M. Drug-induced hyperthermia in critical care. J Intensive Care Soc. 2015; 16(4):306-311. doi:10.1177/1751143715583502

Table 1: Laboratory parameters of the study patient

\begin{tabular}{|c|c|c|c|c|c|c|c|c|}
\hline $\begin{array}{l}\text { Day of } \\
\text { hospitalization }\end{array}$ & 0 & 1 & 2 & 3 & 4 & 5 & 6 & 7 \\
\hline $\mathrm{ALC} / \mu \mathrm{l}$ & 400 & 900 & 900 & 600 & 700 & 1200 & 1200 & 2500 \\
\hline Platelets/ $\mu 1$ & 303000 & 386000 & 427000 & 502000 & 500000 & 422000 & 417000 & 249000 \\
\hline CRP (mg/dl) & 20 & 21.4 & & 3.3 & 1.47 & 1 & 0.647 & 0.549 \\
\hline PCT ( ng/ml & 1.45 & 2.26 & 1.01 & 0.50 & 0.31 & 0.27 & 0.40 & 0.56 \\
\hline LDH U/1 & 645 & 434 & & & & & 471 & 720 \\
\hline CPK U/1 & 308 & 115 & & & & & & 12746 \\
\hline $\begin{array}{l}\text { D Dimer FEU } \\
\mathrm{ng} / \mathrm{ml}\end{array}$ & $>10000$ & 5914 & 3282 & & & & 1155 & 809 \\
\hline $\begin{array}{l}\text { Serum } \\
\text { creatinine } \\
\mathrm{mg} / \mathrm{dl}\end{array}$ & 0.85 & 1.1 & 1.15 & 0.91 & 0.95 & & & 1.07 \\
\hline $\begin{array}{l}\text { LFT, RFT, } \\
\text { coagulation } \\
\text { profile }\end{array}$ & & & & & mal & & & \\
\hline
\end{tabular}

ALC: absolute lymphocyte count, CRP: C reactive protein: PCT: Procalcitonin, LDH: Lactate dehydrogenase, CPK: creatinine phosphokinase, LFT: liver function tests 